\title{
PEMANFAATAN BAKTERI HASIL ISOLASI DARI TPA (TEMPAT PEMBUANGAN AKHIR) GUNUNG TUGEL KABUPATEN BANYUMAS SEBAGAI AGEN BIODEGRADASI POLIMER POLIEUGENOL
}

\author{
Puji Lestari, Zusfahair, Dian Riana Ningsih, Senny Widyaningsih \\ Program Studi Kimia, Jurusan MIPA \\ Fakultas Sains dan Teknik, Universitas Jenderal Soedirman, Purwokerto
}

\begin{abstract}
A number of microbes are known to have ability to degrade synthetic polymers such as polyeugenol. This research was attempted to know the genus of bacterium that isolated from Gunung Tugel garbage dumping land which is able to degrade polyeugenol and to characterize polyeugenol before and after biodegradation process using this bacterium. Pure eugenol was polymerized into polyeugenol by adding concentrated sulphate acid, and then formed become a thin film. Bacterium which is isolated from Gunung Tugel garbage dumping land was suggested as Acinetobacter sp. Polyeugenol thin film was incubated with this bacterium with various incubation times $5,10,15,20,25,30$ and 60 days. Thin film then was characterized including melting point value, percentage of weight loss, molecular weight, and the function groups by FTIR. Melting point of initial polyeugenol was $135-137^{\circ} \mathrm{C}$ and after biodegradation was $98-100^{\circ} \mathrm{C}$. Percentage average of loss weight was $0.5637 \%(\mathrm{~b} / \mathrm{v})$. Molecular weight of polyeugenol before degradation was 61.472.882,91 g/mole and after biodegradation was 5,542,915.464 g/mole. FTIR spectrum percentage of transmittance of polyeugenol after biodegradation was decreased.
\end{abstract}

Keywords: polyeugenol, thin film, biodegradation, Acinetobacter sp., Gunung Tugel

\section{PENDAHULUAN}

Polimer plastik dianggap sebagai salah satu ciri kemunculan zaman modern yang ditandai dengan kehidupan yang serba praktis dan nyaman. Kemudahan yang diberikan oleh bahan-bahan yang terbuat dari polimer plastik berdampak negatif terhadap masalah pencemaran lingkungan. Pasaribu (2004) menyatakan bahwa polimer plastik memiliki tekstur yang kuat sehingga bersifat tahan lama yang menyebabkan sampah polimer plastik sulit didegradasi oleh mikroba.

Masalah pencemaran plastik mendorong perhatian para peneliti lingkungan untuk mencari bahan plastik ramah lingkungan. Plastik ini biasa dikenal dengan istilah biodegradable plastics atau bioplastik, yakni plastik yang dapat dibentuk atau dirombak secara biologis oleh mikroba (Surono, 2004). Polimer plastik yang biodegradable dapat diperoleh dari alam, salah satunya dari minyak cengkeh yang komponen utamanya adalah senyawa eugenol yang dipolimerisasi menjadi polieugenol. Polieugenol berpotensi untuk dijadikan bahan pengemas ramah lingkungan karena tidak mudah rusak oleh panas dan merupakan polimer sintetik yang monomernya berasal dari bahan alam (Susilowati dkk, 2003)

Banyak penelitian ditujukan untuk mengeksplorasi mikroba-mikroba pendegradasi polimer sintetis yang diisolasi dari tanah dan salah satunya telah dilakukan oleh Kathiresan (2003). Berdasarkan hasil penelitiannya, diperoleh beberapa mikroba yang diketahui memiliki kemampuan untuk mendegradasi polimer yaitu Streptococcus sp, Staphylococcus sp, Micrococcus sp, Moraxella sp, dan Pseudomonas sp dari golongan bakteri, 
Aspergillus glaucus dan A. niger dari golongan fungi.

Salah satu tempat potensial ditemukannya mikroba-mikroba pendegradasi polimer sintetis adalah TPA (Tempat Pembuangan Akhir) sampah Gunung Tugel. TPA ini terletak di Gunung Tugel, Desa Kedungrandu Kecamatan Patikraja Kabupaten Banyumas dengan area seluas 5 hektar. Sampah yang dibuang berupa sampah organik $(80,03 \%)$ dan sisanya berupa sampah anorganik $(19,97 \%)$ (Oktifani, 2000). Sistem pengelolaan TPA Gunung Tugel menggunakan sistem controlled landfill yaitu penutupan sampah dengan lapisan tanah yang dilakukan setelah TPA penuh dengan timbunan sampah yang dipadatkan. Hal ini memberikan peluang besar bahwa tanah di TPA Gunung Tugel mengandung banyak mikroba pendegradasi polimer plastik. Oleh karena itu dilakukan penelitian untuk mengeksplorasi mikroba-mikroba dari TPA Gunung Tugel yang berpotensi mendegradasi polimer sintetik yaitu polieugenol.

\section{METODE PENELITIAN \\ Bahan dan Alat}

Bahan-bahan yang digunakan dalam penelitian ini adalah sampel tanah TPA Gunung Tugel, eugenol 99,94\% (USP Grade dari PT. Indesso Aroma, Purwokerto), asam sulfat pekat, etanol $70 \%$, etil asetat, aquades, medium Nutrient agar (NA), medium Nutrient Broth (NB), Kalium Bromida. Alat-alat yang digunakan dalam penelitian ini yaitu corong pisah, gelas piala, gelas objek, magnetic stirrer, plat baja, cawan petri, tabung reaksi, labu erlenmeyer, jarum ose, drugalsky, autoklaf, shaker incubator, spektrometer FTIR, alat penentu titik leleh, neraca analitik, termometer, kertas $\mathrm{pH}$, pembakar bunsen.

\section{Penyiapan Sampel (Setiawan, 2000)}

Tanah diambil dari beberapa titik di TPA Gunung Tugel. Sampel tanah diambil dari tanah dengan cara menggali $10 \mathrm{~cm}$ dari permukaan tanah kemudian diukur $\mathrm{pH}$ dan suhunya secara in situ. Tanah yang didapatkan lalu dimasukkan ke dalam botol steril.

\section{Inokulasi Bakteri}

Sampel tanah yang telah diambil, dimasukkan sebanyak $2 \mathrm{~g}$ ke dalam medium NB kemudian digoyang dengan shaker selama 1 x 24 jam.

\section{Isolasi Bakteri}

Sampel tanah yang telah diinokulasikan lalu diambil dengan pipet mikro sebanyak $0,1 \mathrm{~mL}$, dipindahkan ke dalam cawan petri yang berisi medium NA dengan cara disebar dengan batang kaca bengkok (drugalsky) secara aseptis kemudian diinkubasi pada suhu asal selama 1 x 24 jam.

\section{Pencarian Koloni Tunggal (Lay, 1994)}

Satu ose bakteri diambil dari medium NA dan dipindahkan ke cawan petri yang berisi medium NA baru, digoreskan pada permukaan medium dengan teknik goresan kuadran secara aseptis. Teknik ini diulangi sampai didapat koloni tunggal.

\section{Uji Biodegradasi Pendahuluan}

Polieugenol steril dengan berat tertentu dimasukkan ke dalam cawan petri yang telah berisi medium dan masing-masing isolat bakteri secara aseptis, kemudian cawan petri disimpan pada suhu asal selama 14 hari. Proses biodegradasi dihentikan dengan mengambil polieugenol dari dalam medium, kemudian dioven pada suhu $50^{\circ} \mathrm{C}$ untuk menghilangkan sisa airnya. Polieugenol terbiodegradasi ditimbang untuk mengetahui persentase kehilangan bobotnya. 


\section{Identifikasi Bakteri}

Bakteri ditumbuhkan pada medium tumbuh untuk mengetahui jenisnya. Bakteri diidentifikasi melalui uji morfologi secara langsung dengan mikroskop dan dengan pewarnaan gram serta uji fisiologis yang meliputi uji amilolitik, proteolitik, lipolitik, fermentasi karbohidrat, reduksi nitrat serta uji katalase.

\section{Polimerisasi Polieugenol dan Uji Biodegradasi Lanjutan \\ Polimerisasi polieugenol (Susilowati dkk, 2003)}

Sebanyak $50 \mathrm{~mL}$ eugenol murni dimasukkan ke dalam gelas piala, kemudian ditambahkan $\mathrm{H}_{2} \mathrm{SO}_{4}$ pekat tetes demi tetes (sambil diaduk) dari corong pisah hingga terbentuk jeli padat berwarna merah. Jeli ini dilarutkan ke dalam etil asetat, lalu dicuci dengan air untuk menghilangkan sisa asam. Polieugenol yang terbentuk dikarakterisasi puncak serapan menggunakan FTIR dan titik leleh dengan alat penentu titik leleh.

\section{Pembuatan film tipis polieugenol}

Film tipis polieugenol dibuat dengan mencelupkan cetakan kaca yang berukuran $1 \mathrm{~cm} \quad \mathrm{x} \quad 1 \mathrm{~cm}$ ke dalam polieugenol yang dilarutkan dalam kloroform, kemudian larutan dibiarkan menguap di udara terbuka.

\section{Uji biodegradasi (Rohaeti dkk, 2004)}

Uji biodegradasi dilakukan dengan variasi waktu selama $0,5,10,15$, 20,25 , dan 30 hari pada suhu asal. Setiap perlakuan diulang sebanyak 3x. Polieugenol steril dengan berat tertentu dimasukkan ke dalam cawan petri yang telah berisi medium dan bakteri secara aseptis, kemudian cawan petri disimpan pada suhu asal sesuai dengan variasi waktu yang telah ditentukan. Proses biodegradasi dihentikan dengan mengambil polieugenol dari dalam medium, kemudian dioven pada suhu 50 ${ }^{\circ} \mathrm{C}$, dan polieugenol siap dikarakterisasi. Karakterisasi yang dilakukan pada film polieugenol yang terbiodegradasi ini adalah penentuan titik leleh, persentase kehilangan bobot, bobot molekul dan analisis gugus fungsi.

\section{Karakterisasi Polieugenol \\ Penentuan titik leleh (Hartomo, 1993)}

Titik leleh polieugenol ditentukan menggunakan alat penentuan titik leleh. Sejumlah kristal polieugenol dimasukkan ke dalam pipa kapiler setinggi $0,5 \mathrm{~cm}$, kemudian pasang pipa kapiler pada alat penentuan titik leleh. Data jarak titik leleh diperoleh saat kristal dalam pipa kapiler mulai meleleh sampai semuanya leleh.

\section{Penentuan persentase kehilangan bobot (Iswanto dkk, 2002) \\ Penentuan persentase kehilangan} bobot ditentukan berdasarkan penghitungan bobot awal polieugenol sebelum uji biodegradasi dan bobot akhir setelah uji biodegradasi.

$\%$ Kehilangan bobot $=\frac{(\text { bobot awal }- \text { bobot akhir })}{\text { bobot awal }} \times 100 \%$

\section{Penentuan bobot bolekul}

Penentuan bobot molekul ditentukan berdasarkan penentuan bobot molekul awal polieugenol sebelum uji biodegradasi dan bobot molekul akhir setelah uji biodegradasi. Polieugenol dilarutkan dalam kloroform dengan konsentrasi 1, 2, 3, 4, 5, dan $6 \mathrm{mg} / \mathrm{L}$, kemudian masing-masing larutan tersebut dialirkan dalam viskometer Ostwald sehingga diperoleh laju aliran untuk masing-masing variasi konsentrasi. Data ini kemudian dihitung dengan persamaan Mark-Houwink-Sakurada untuk menentukan berat molekul polimer.

Keterangan:

$$
[\eta]=\mathrm{KM}^{\mathrm{a}}
$$

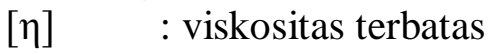

M : massa molekul nisbi

$\mathrm{K}$ dan a : tetapan yang khas untuk sistem polimer-pelarut tertentu. 
Analisis dengan FTIR (Silverstein dkk, 1986)

Analisis gugus fungsi dilakukan menggunakan alat spektrofotometer inframerah. Sejumlah kecil polieugenol kering $(<1 \mathrm{mg})$ dicampur rata dengan $\pm 100 \mathrm{mg} \mathrm{KBr}$, selanjutnya dilakukan analisis dengan FTIR.

\section{HASIL DAN PEMBAHASAN Polimerisasi Polieugenol}

Polimerisasi

polieugenol menggunakan eugenol murni sebagai monomer. Polimerisasi eugenol berlangsung pada suhu kamar secara eksotermis yang ditandai dengan meningkatnya suhu sistem dan reaksinya yang eksplosif. Menurut Cowd (1982), polimerisasi monomer cair bersifat sangat eksotermis dan reaksinya bisa sulit dikendalikan. Polimer biasanya larut dalam monomernya sehingga kekentalan sistem meningkat dan sukar diaduk, namun cara polimerisasi ini biasanya memberikan hasil yang relatif murni.

Polimerisasi telah terjadi ditandai dengan perubahan fisik seperti perubahan warna, pembentukan padatan dan terbentuknya gas (Cowd, 1982). Perubahan warna larutan eugenol menjadi merah, terbentuknya jeli menandakan telah terjadi polimerisasi. Jeli yang terbentuk dilarutkan dalam etil asetat, kemudian diuapkan untuk mendapatkan polimer murni. Penguapan dilakukan di udara terbuka sampai polimer membentuk padatan kembali. Padatan yang terbentuk digerus sampai menjadi serbuk agar lebih mudah dibentuk menjadi film tipis.

\section{Pembuatan Film Tipis Polieugenol}

Polieugenol kemudian dibentuk menjadi film tipis. Berdasarkan pengamatan, film yang terbentuk bersifat cukup kuat dan tidak mudah patah. Film polimer yang terbentuk terdapat lubang atau kawah karena adanya gelembung gas yang terperangkap pada saat proses pencelupan. Menurut Christian (2001), tujuan pembuatan film tipis agar memudahkan karakterisasi sebelum dan sesudah biodegradasi terutama dalam mendeteksi penurunan bobot polieugenol, memudahkan penanganan serta identifikasi aktivitas biodegradasi.

Polieugenol ini kemudian diuji titik lelehnya. Berdasarkan pengamatan film polieugenol yang terbentuk dan titik leleh yang tinggi yaitu $135-137^{\circ} \mathrm{C}$, dapat disimpulkan bahwa polieugenol ini dapat menggantikan plastik yang kuat dan tahan panas akan tetapi polieugenol ini belum murni karena rentang titik lelehnya lebih dari $1^{\circ} \mathrm{C}$.

\section{Isolasi Bakteri Pendegradasi Polieugenol}

Sampel tanah yang diambil dari TPA Gunung Tugel diukur $\mathrm{pH}$ dan suhunya secara in situ, menghasilkan $\mathrm{pH}$ 8 dan suhu $30^{\circ} \mathrm{C}$. Medium cawan yang telah diberi kultur bakteri dari medium inokulasi ditumbuhi berbagai macam bakteri. Pembuatan biakan murni dilakukan agar dapat dihasilkan bakteri yang berasal dari satu famili dengan memindahkan bakteri-bakteri ke dalam medium NA yang baru menggunakan metode goresan kuadran. Bakteri-bakteri kemudian terpisah-pisah membentuk koloni-koloni tunggal dan menghasilkan lima biakan murni bakteri yang dikode dengan bakteri GT1, GT2, GT3, GT4 dan GT5 (GT = Gunung Tugel).

Uji biodegradasi pendahuluan dilakukan terhadap kelima isolat bakteri untuk mengetahui bakteri yang mampu mendegradasi polieugenol. Tabel 1 menunjukkan kemampuan masingmasing isolat dalam mendegradasi polieugenol. 
Tabel 1. Hasil uji biodegradasi pendahuluan

\begin{tabular}{cccccc}
\hline Isolat & \multirow{2}{*}{$\begin{array}{c}\text { Bobot awal } \\
(\mathrm{mg})\end{array}$} & $\begin{array}{c}\text { sebelum } \\
\text { dioven }\end{array}$ & $\begin{array}{c}\text { sesudah } \\
\text { dioven }\end{array}$ & $\begin{array}{c}\text { kehilangan } \\
\text { bobot }\end{array}$ & $\begin{array}{c}\text { Persentase } \\
\text { kehilangan bobot } \\
(\%)\end{array}$ \\
\hline GT1 & 0,6438 & 0,6437 & 0,6423 & 0,0015 & 0,2330 \\
GT2 & 0,6715 & 0,6708 & 0,6683 & 0,0032 & 0,4760 \\
GT3 & 0,6748 & 0,6774 & 0,6748 & 0,0000 & 0,0000 \\
GT4 & 0,6160 & 0,6166 & 0,6150 & 0,0010 & 0,1620 \\
GT5 & 0,6301 & 0,6320 & 0,6289 & 0,0012 & 0,1900 \\
\hline
\end{tabular}

Berdasarkan Tabel 1, isolat GT1, GT2, GT4, dan GT5 mampu mendegradasi polieugenol dengan persentase kehilangan bobot polieugenol berturutturut sebesar 0,$233 ; 0,476 ; 0,162$; dan $0,190 \%$. Isolat bakteri GT3 tidak mampu mendegradasi polieugenol. Persentase kehilangan bobot terbesar adalah isolat bakteri GT2 yaitu sebesar $0,476 \%$ yang selanjutnya dipakai untuk uji biodegradasi lanjutan.

\section{Identifikasi Bakteri Pendegradasi Polieugenol}

Isolat bakteri GT2 selanjutnya diidentifikasi untuk menentukan genusnya serta dipakai untuk uji biodegradasi lanjutan. Identifikasi dilakukan terhadap sifat fisiologi, morfologi sel dan morfologi koloni.

$$
\text { Isolat GT2 mampu }
$$

memfermentasi glukosa dan fruktosa, memiliki sifat gram positif, menghasilkan enzim katalase, tidak mampu mereduksi nitrat. Ciri morfologinya berbentuk kokus, tidak mampu melakukan oksidasi, serta memiliki ciri koloni kecil, bentuk yang berlekuk, tepi berlekuk, ukuran kecil, warna jernih, permukaan mengkilap, elevasinya cembung rendah. Berdasarkan ciri-ciri tersebut maka diduga bahwa genus bakteri tersebut adalah Acinetobacter sp.

Uji Biodegradasi Lanjutan dan Karakterisasi Polieugenol Setelah Biodegradasi

\section{Penentuan Titik Leleh}

Film tipis yang telah diinkubasi selama 30 hari diambil dan dikarakterisasi titik lelehnya. Terjadi penurunan titik leleh polieugenol sebelum biodegradasi dari kisaran suhu $135-137^{\circ} \mathrm{C}$ menjadi $98-100^{\circ} \mathrm{C}$ setelah proses biodegradasi. Menurut Bikiaris, dkk (2006) proses biodegradasi menurunkan titik leleh. Penurunan titik leleh ini terjadi akibat biodegradasi dengan adanya pengurangan rantai karbon oleh Acinetobacter sp.

\section{Penentuan Persentase Kehilangan Bobot}

Polieugenol setelah biodegradasi mengalami persentase kehilangan bobot rata-rata sebesar 0,$04 ; 0,204 ; 0,294$; 0,$519 ; 0,795 ; 1,015$; dan $1,079 \%$ pada waktu inkubasi berturut-turut $5,10,15$, 20, 25, 30 dan 60 hari. Hubungan waktu inkubasi dan persentase kehilangan bobot dapat dilihat pada Gambar 1. 


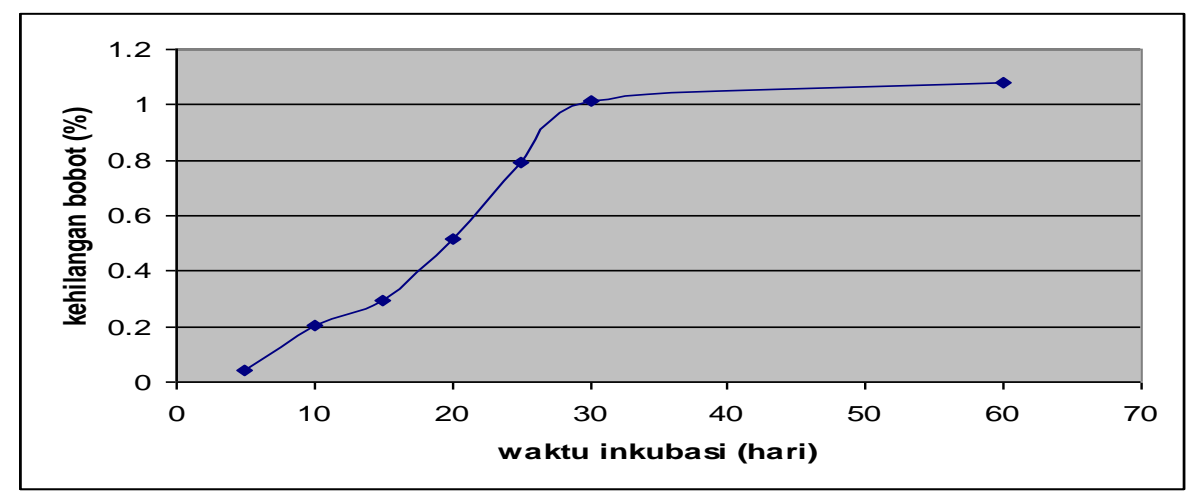

Gambar 1 Kurva hubungan waktu inkubasi dengan persentase kehilangan bobot polieugenol

Berdasarkan Gambar 1 diketahui bahwa semakin lama waktu inkubasi maka persentase kehilangan bobot polieugenol semakin besar. Peningkatan persentase kehilangan bobot rata-rata $0,196 \%$ tiap penambahan waktu inkubasi, akan tetapi setelah waktu inkubasi 30 hari persentase kehilangan bobot relatif konstan. Menurut Iswanto, dkk (2002), hal ini terjadi karena kemampuan bakteri dalam mendegradasi polieugenol menurun akibat banyaknya bakteri yang mati. Kehilangan bobot polieugenol dapat juga terjadi karena adanya reaksi pemutusan rantai polimer yang disebabkan oleh zat kimia dalam medium selama proses biodegradasi. Hal ini dikoreksi menggunakan kontrol negatif, yaitu polieugenol yang diperlakukan sama dengan polieugenol yang dibiodegradasi tetapi tidak mengandung bakteri. Reaksi yang timbul selain reaksi yang disebabkan oleh bakteri serta kehilangan bobot karena adanya sisa air yang terperangkap dalam polieugenol akan tercakup dalam perubahan bobot yang dialami kontrol negatif. Cara ini dapat dipakai karena kontrol negatif sama sekali tidak ditumbuhi bakteri atau kontaminan lain selama disimpan dalam medium (Andriyani, 2001).

\section{Penentuan Bobot molekul}

Bobot molekul polieugenol sebelum dan sesudah biodegradasi ditentukan pada berbagai variasi konsentrasi dengan metode pengukuran viskositas menggunakan viskometer Ostwald. Hubungan antara viskositas tereduksi dengan konsentrasi masingmasing larutan polieugenol sebelum uji biodegradasi dapat dilihat pada Gambar 2.

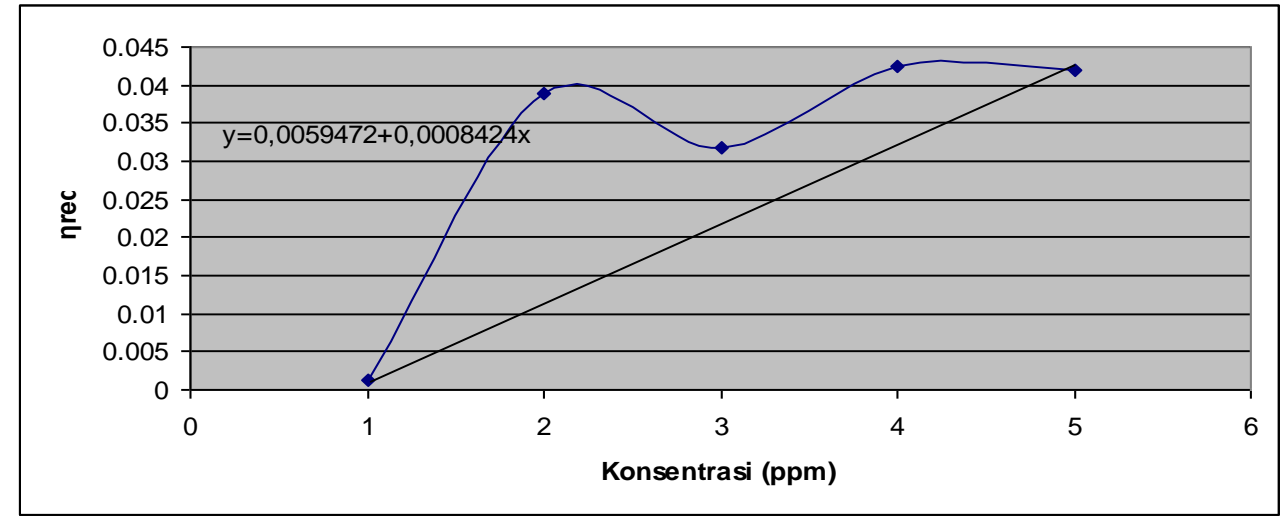

Gambar 2. Kurva viskositas tereduksi terhadap konsentrasi larutan polieugenol dalam kloroform sebelum biodegradasi 
Berdasarkan plot antara viskositas tereduksi dengan konsentrasi didapat viskositas intrinsik sebelum biodegradasi sebesar 0,0059472. Bobot molekulnya ditentukan dengan persamaan MarkHouwink Sakurada dan didapat $61.472 .882,91 \mathrm{~g} / \mathrm{mol}$

Nilai viskositas intrinsik setelah uji biodegradasi meningkat sebesar
0,0095530. Hal ini berarti nilai viskositas berbanding terbalik dengan penurunan bobot molekul rata-rata. Hubungan viskositas tereduksi dengan konsentrasi masing-masing larutan polieugenol sesudah uji biodegradasi dapat dilihat pada Gambar 3.

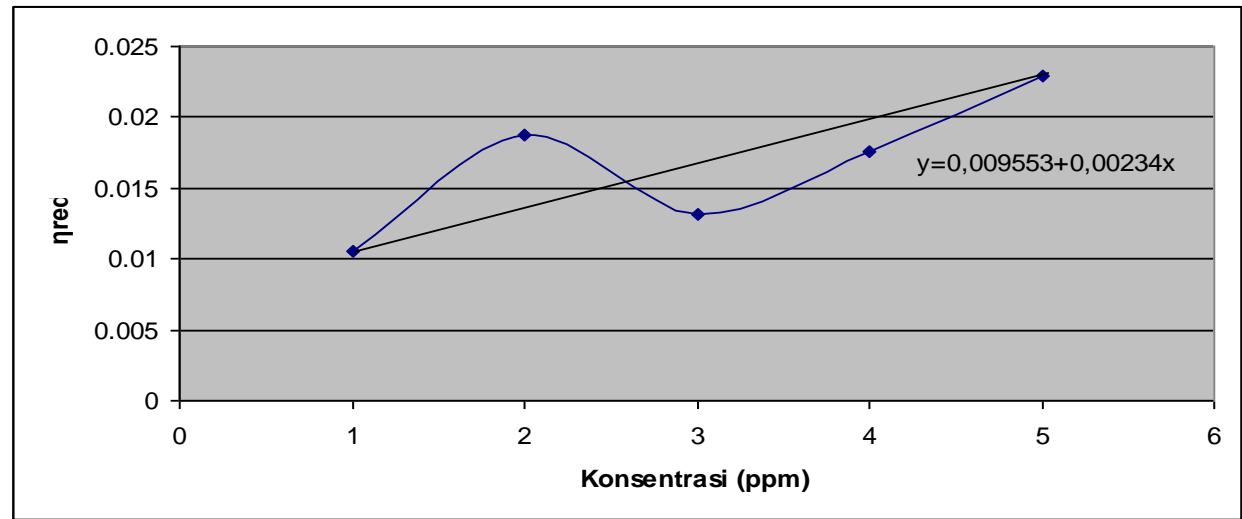

Gambar 3. Kurva viskositas tereduksi terhadap konsentrasi larutan polieugenol dalam kloroform setelah biodegradasi

Hasil perhitungan bobot molekul polieugenol dengan persamaan MarkHouwink Sakurada adalah sebesar 5.542.915,484 g/mol. Menurut Rohaeti (2004) menurunnya bobot molekul ratarata polieugenol setelah uji biodegradasi menunjukkan terjadinya biodegradasi polieugenol yang ditunjukkan oleh pengurangan rantai karbon pada polieugenol.

Pemutusan rantai polimer dapat terjadi secara sistematik dari ujung rantai polimer (tipe ekso) atau secara acak pada rantai polimer (tipe endo). Degradasi yang terjadi didominasi oleh tipe ekso, maka pengurangan berat molekul hasil degradasi mempunyai nilai yang sangat besar (Kawabata et al,. 1994 dalam
Nurmayasari, 2007). Selisih persentase kehilangan bobot molekul sangat signifikan yaitu 55.929.967,426 g/mol, hal ini berarti degradasi didominasi oleh tipe ekso.

\section{Analisis Gugus Fungsi Dengan FTIR}

Menurut Iswanto dkk (2002), analisis gugus fungsi dengan FTIR dilakukan untuk mendukung hasil-hasil karakterisasi sebelumnya dengan membandingkan spektrum eugenol murni, polieugenol sebelum terdegradasi dan polieugenol sesudah terdegradasi. Hasil karakterisasi berupa spektrum FTIR yang menunjukkan puncak-puncak spesifik untuk senyawa eugenol murni dapat dilihat pada Gambar 4. 


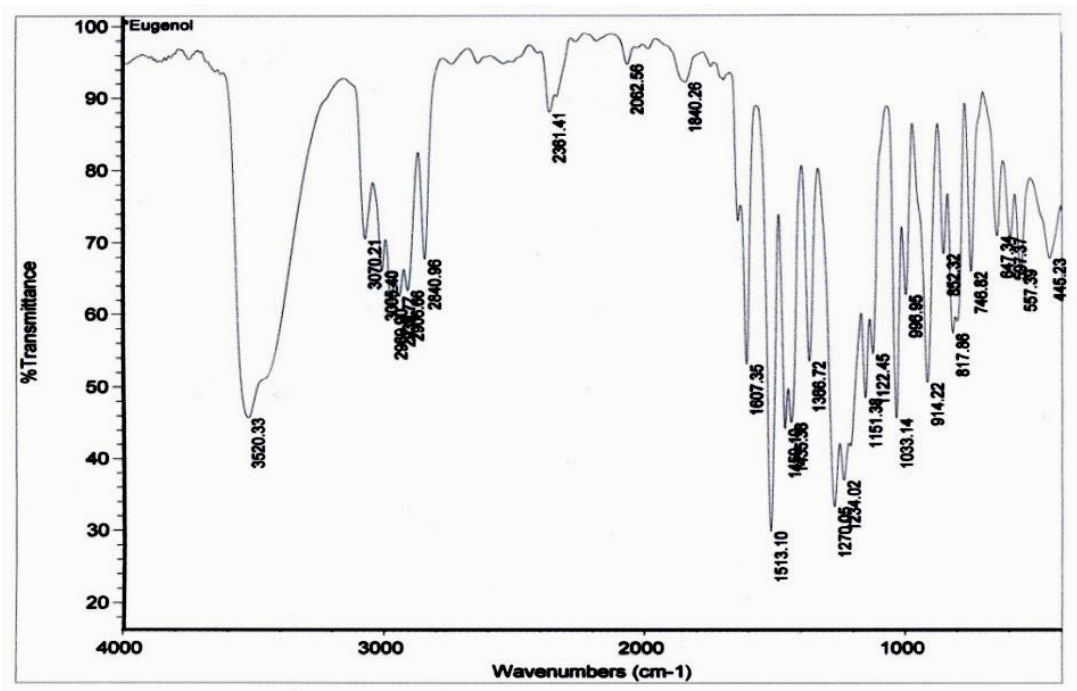

Gambar 4. Spektrum FTIR Eugenol Murni

Serapan-serapan pada spektrum menunjukkan serapan khas eugenol murni. Gugus $\mathrm{OH}$ ditunjukkan pada serapan $3520,33 \mathrm{~cm}^{-1}$ yang lebar, gugus C-C ditunjukkan pada serapan 2969,90 $\mathrm{cm}^{-1}$ dan $2840,96 \mathrm{~cm}^{-1}$ yang tajam, gugus $\mathrm{C}=\mathrm{C}$ ditunjukkan pada serapan 1607,35 $\mathrm{cm}^{-1}$, gugus cincin aromatik pada serapan 1513,10 dan $1459,10 \mathrm{~cm}^{-1}$ yang diperkuat dengan gugus aromatik tersubtitusi pada serapan $817,86 \mathrm{~cm}^{-1}$, gugus $\mathrm{CH}_{2}$ pada serapan $1435,38 \mathrm{~cm}^{-1}$, serta gugus vinil ditunjukkan pada serapan kuat 996,95 dan $914,22 \mathrm{~cm}^{-1}$. Puncak serapan pada $2361,41 \mathrm{~cm}^{-1}$ menandakan gugus $\mathrm{C} \equiv \mathrm{N}$ yang merupakan pengotor karena dalam struktur eugenol tidak terdapat gugus tersebut. Spektrum FTIR polieugenol sebelum biodegradasi dapat dilihat pada Gambar 5.

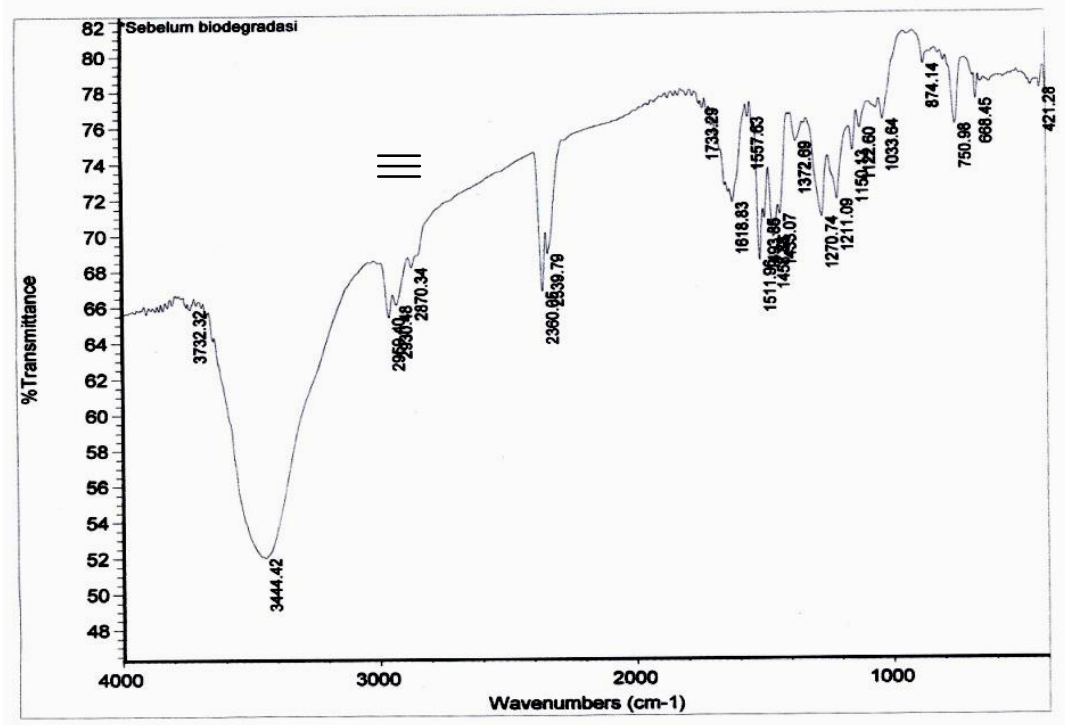

Gambar 5. Spektrum FTIR Polieugenol Sebelum Biodegradasi

Berdasarkan spektrum tersebut dapat dilihat bahwa persen transmitansi serapan gugus olefin $\left(1606,35 \mathrm{~cm}^{-1}\right)$ menurun dan serapan gugus vinil $(996,95$ dan 914,22 $\mathrm{cm}^{-1}$ ) hilang. Menurut Handayani (2001), hal ini berarti telah terjadi reaksi polimerisasi yakni reaksi adisi terhadap ikatan rangkap yang 
terdapat dalam senyawa eugenol. Secara fisik dapat dilihat bahwa polimer yang dihasilkan berwujud padat. Puncak serapan pada 2360,05 $\mathrm{cm}^{-1}$ masih muncul sampel yang masih mengandung pengotor.
Karakterisasi polieugenol dilakukan lagi menggunakan FTIR setelah biodegradasi selama 30 hari. Puncak-puncak yang muncul hampir sama dengan puncak-puncak polieugenol sebelum biodegradasi seperti terlihat pada Gambar 6.

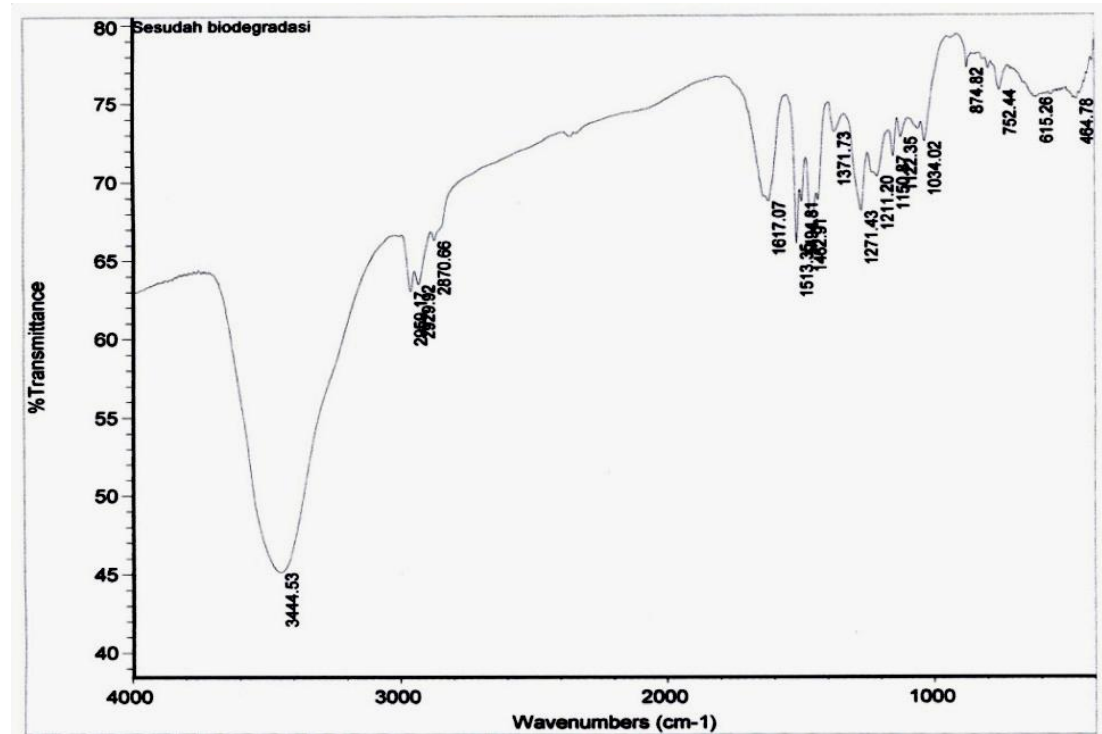

Gambar 6. Spektrum FTIR Polieugenol Terbiodegradasi

Perbedaannya adalah pada nilai persen transmitansi gugus karbon jenuh, gugus olefin, gugus metilen, serta gugus aromatik menurun. Jika dibandingkan dengan polieugenol sebelum biodegradasi terjadi penurunan persen transmitan pada puncakpuncak khas polieugenol. Menurut Andriyani (2001), menurunnya persen transmitansi menunjukkan ada sejumlah ikatan dalam polieugenol yang terputus dan menandakan terjadinya proses biodegradasi. Puncak serapan pada 2360, $05 \mathrm{~cm}^{-1}$ tidak muncul, hal ini berarti sudah tidak terdapat pengotor.

\section{KESIMPULAN}

1. Genus bakteri hasil isolasi dari TPA Gunung Tugel yang mampu mendegradasi polieugenol adalah Acinetobacter sp.

2. Polieugenol sebelum dan sesudah biodegradasi memiliki karakteristik berbeda. Polieugenol sebelum biodegradasi memiliki kisaran titik leleh $135-137^{\circ} \mathrm{C}$ serta bobot molekul 61.472.882,91 g/mol. Polieugenol setelah biodegradasi memiliki kisaran titik leleh yang lebih rendah yaitu 98$100^{\circ} \mathrm{C}$ dan bobot molekul 5.542.915,484 g/mol. Persentase kehilangan bobot rata-rata adalah $0,5637 \% \quad(\mathrm{~b} / \mathrm{v})$. Spektrum FTIR polieugenol sebelum biodegradasi berbeda dengan spektrum FTIR polieugenol sesudah biodegradasi.

\section{DAFTAR PUSTAKA}

Andriyani, N. 2001. Biodegradasi Poliester Linear dengan Bakteri Tertentu. Skripsi (tidak dipublikasikan). Fakultas MIPA ITB. Bandung.

Bikiaris, D.N., G.Z. Papageorgiou and D.S. Achilias. 2006. Synthesis and Comparative Biodegradability Studies of Three Poly(alkaline 
succinate)s. Polymer Degradation and Stability. www.elsevier.com/locate/polydegst ab diakses 11 januari 2008.

Christian, E. 2001. Studi Biodegradasi Kopolimer PatiPolimetilmetakrilat. Skripsi (tidak dipublikasikan). Fakultas MIPA ITB. Bandung.

Cowd, M.A. 1982. Kimia Polimer. Penerjemah : Drs. Harry Firman. Penerbit ITB. Bandung.

Handayani, W. 2001. Sintesis Polieugenol Dengan Katalis Asam Sulfat. Jurnal Ilmu Dasar, 2 (2) : 103-110.

Hartomo, A.J. 1993. Penuntun Analisis Polimer Aktual. Penerbit Andi offset. Yogyakarta.

Iswanto, P., N.M. Surdia dan I.M. Arcana. 2002. Biodegradasi Poli(Trimetilen Adipat) dengan Lumpur Aktif. Majalah Ilmiah UNSOED No. 1/Th. XXVII. Edisi Maret. Purwokerto.

Kathiresan, K. 2003. Polythene and Plastic-Degrading Microbes from The Mangrove Soil. Revista Biology Tropical Journal, 51 (3) : 629-634.

Lay, B. W. 1994. Analisis Mikroba di Laboratorium. PT. Raja Grafindo Persada. Jakarta.

Nurmayasari, Y. 2007. Sintesis Polieugenol Dari Minyak Daun Cengkeh dan Uji FotoBiodegradasinya Dengan Lumpur Aktif. Skripsi (tidak dipublikasikan). Fakultas MIPA Unsoed. Purwokerto.
Oktifani, R. 2000. Kandungan Logam Berat Kadmium dan Seng dalam Tubifex yang Tercemar Leachate TPA Sampah Gunung Tugel Purwokerto. Skripsi (tidak dipublikasikan). Fakultas Biologi Unsoed. Purwokerto.

Pasaribu, N. 2004. Berbagai Ragam Pemanfaatan Polimer. (on-line) http://www.library.usu.ac.id/jurnal. php\%3fop\%3d387+polimer\&hl=id \&gl diakses 10 Februari 2007.

Rohaeti, E., N. M. Surdia, C. L. Radiman dan E. Ratnaningsih. 2004. Pengaruh Dua Macam Perlakuan Mikroorganisme terhadap Kemudahan Degradasi Poliuretan Hasil Sintesis dari Monomer Polietilen Glikol Berat Molekul 400 dengan Metilen-4,4' difenildiisosianat. Proceeding ITB Sains \& Teknologi, 36 A (1) : 1-9.

Silverstein, R.M., G.C. Bassler dan T.C. Morril. $1986 . \quad$ Penyidikan Spektrometrik Senyawa Organik. Alih bahasa : A.J. Hartomo dan Anny Victor Purba. Edisi ke-4. Erlangga. Jakarta.

Surono, ZSM. 2004. Pabrik Terkecil Di Dunia Penghasil Plastik. (on-line) http://www.bila/insightmagazine.htm diakses 10 Februari 2007.

Susilowati, S.S., P. Iswanto dan Suwandri. 2003. Polimerisasi eugenol, Fraksinasi Polimer dan Penentuan Berat Molekul Fraksi Polimer secara Viskometri. Majalah Ilmiah UNSOED. No1/Th. XXIX. Edisi Maret 2003. Purwokerto. 